\title{
Usage and Gratification of Social Media in Higher Education: A Survey on the Perceptions of International Students in Turkey
}

\section{Rajab Idd Muyingo, Marmara University, Istanbul, Turkey}

\begin{abstract}
This study grounded in the user centered media theory of uses and gratification; it investigated on the usage and gratification of social media among international students pursuing higher education in Turkey, through a survey conducted on a sample of international students in Istanbul City, Turkey. The study was quantitative in nature in which structured questionnaires were used to get data on a randomly selected sample. Findings indicate that $68.2 \%$ of the respondents used social media for more than twice a week to interact with peers for studying outside classroom. Likewise, social media platform commonly used included YouTube, Facebook, WhatsApp, Google group and Twitter. As a gratification, the respondents used You Tube to watch educational video clips on lectures delivered from other universities, watched Turkish videos to improve on their Turkish language skills. Facebook and Whatsapp were used for instant messaging, sharing academic information with classmates and professors. Findings indicate that using Social Media positively influenced their lifestyles and helped them to excel academically as reflected in the responses. The study therefore concludes that Social Media is an essential communication tool among international students in Turkey in supporting their higher education.
\end{abstract}

Keywords: Social Media, Gratification, International Students, Education, Turkey 


\section{Introduction}

Social media although it is perceived as an informal environment mainly used for knowledge sharing and as an information source, it has a great capability for communication. According to Gómez et al. (2012) social media have gone universal and students have fully incorporated them into their lives. Social media have become the ideal space in which to exchange information and knowledge in a swift, simple and convenient way. Teachers may be able to take advantage of this situation and of the students' predisposition to using social media to incorporate them into their teaching. They further note that the use of social media, blogs and video applications implies taking information and education to the places that students associate with entertainment and where they may approach them with fewer prejudices (Gómez, Roses \& Farias Pedro, 2012: 2). Basing on this we can note that together with a merely social use, as a space and a route for communication, information and entertainment, social media possess vast potential for the educational sphere and evidence emerged that students are favorably disposed towards the academic use of social media.

Remarkably, in the juncture of the European Higher Education Area (EHEA), social media provides several ways for addressing the challenges of higher education, both from the technical and the educational point of view. In fact some of their inherent characteristics, such as collaboration, free dissemination of information or generation of own content for the construction of knowledge have been applied on an immediate basis to the educational field (De Haro, 2010). This means that the student develops some of the competences highlighted by the EHEA: personal (self-learning and critical thought, recognition of diversity); instrumental (visual culture, computer skills); or systematic (research potential or case-based learning). Social media permit and favour the publication and sharing of information; selflearning; teamwork; communication, both between students and between pupil-teacher; feedback; access to other sources of information that support or even facilitate constructivist learning and collaborative learning; and contact with experts, (Gómez, Roses\& Farias Pedro, 2012: 2). As a whole, all of these social media applications and resources make learning more interactive and significant and above all allow leaning in a more dynamic learning environment. 


\section{Problem Statement}

As the motivation for international students to pursue higher education in Turkey varies from student to student, scholarly opinions also vary in the uses of social media in academia. As Ferdig (2007) notes that social media can support pedagogical approaches of active learning; social learning and student publication, by providing environments and technologies that promote these interactions (Gülbahar, 2014:53). Notably, social media can have promising contributions as an educational tool and environment. Connectedness and socialization dimensions encourage knowledge sharing and communication of users and are a powerful aspect that fosters learning in a collaborative way through discussion and sharing (Gülbahar, 2014:66). Hence, having these advantages in mind, both educators and learners can really benefit from social media in higher education as educators social media can support their instructional processes and students can utilize same opportunity to extend the frontiers of their knowledge.

Nevertheless, with the rapid internationalization of higher education and its warm hospitality, Turkey is a center of attraction for international students from all over the world. In addition to thousands of international students who come to study in Turkey on their own every year, nearly five thousand (5000) international students annually come to Turkey to get either undergraduate or graduate education within the scope of Türkiye Scholarships, (Daily Sabah, 2015). Therefore, given the increasing number of international students in Turkey and with the current technological advancements especially popularity of social media, this study sets out to address the knowledge gap about social media usage and gratification in Higher Education from a standpoint of the international students in Turkey.

This study on Usage and Gratification of Social Media in Higher Education from the International Students' Perceptions had the following objectives:

i) To identify the social media tools which are used by international students pursuing higher education in Turkey.

ii) To examine the educational purposes of social media usage among international students in Turkey.

iii) To explore the academic gratifications attained by international students in the usage of social media 


\section{Literature Review}

According to Ruggiero (2000), computer-mediated communication is reviving the significance of uses and gratifications research. In fact, recent research has begun exploring people's use of the Internet. Ferguson and Perse (2000) explored the usage of the World Wide Web among college students. They found that students often tended to surf for entertainment, to pass time, and to relax. Information uses appeared to be of lesser importance. This suggests that the Web in some ways offers a functional alternative of the $\mathrm{TV}$, they reported. In an exploratory study of Internet use in general (for e-mail as well as the WWW), Papacharissi and Rubin (2000) found five primary motives. The most salient was information seeking, followed by entertainment, convenience, passing time and interpersonal utility. They also reported evidence for an Internet-related distinction between instrumental and ritualized use. (Cited in David, 2002:83). Social media usage is perceived differently from traditional or industrial media in many ways, including quality, reach, frequency, usability, immediacy, and permanence. Social media operate in a dialogic transmission system many sources to many receivers. This is in contrast to traditional media that operates under a monologue transmission model of one source to many receivers.

\section{Social Media Tools}

Social media technology has been growing significantly to support users to gain access to valuable knowledge through different resources. Kaplan and Haenlein (2010) cited in Naghmeh (2000) discuss that although some of the technologies are apparently distinguished as social media, such as Wikipedia, YouTube, Facebook, and some virtual environments, there is no systematic way to differ and categorize applications. However, this study, equally considers social media as defined by (Naghmeh 2000) as a utility tool to integrate online technologies and educational learning to support and develop education. This means that technologies used by learners, which they believe is important and supportive for their educational learning can be considered as social media. Various functions, in and outside online learning management systems, support students' interactions synchronously and asynchronously. (Naghmeh 2000:16).

In March 2016, eBizMBA ranked the top 15 most popular social media sites, by estimated users namely, as Facebook: The networking site used to connect with friends, family or promoting businesses. Twitter: as mostly a blogging networking site. LinkedIn as a 
networking site mostly used by professional with focuses on business. Pinterest as a site where networkers post new ideas, "do-it-yourselves", and theme-based posts. Google Plus+ as $\mathrm{s}$ a social networking site owned by Google, that is similar to Twitter and Facebook. Tumblr, like Twitter, as a blogging network. Instagram as a photo/video sharing app. Flickr as an image and video hosting app. Vine as primarily a video sharing app. Meetup as a networking site used to connect with local groups. (http://www.ebizmba.com, 2016).

Despite the multiplicity of social media sites accessed and used by the public for different purposes, this study focused much on social media perceived to be used by students in higher education for academic purposes. These include, Facebook, YouTube, Twitter, LinkedIn, Google Groups. Wikipedia, Twitter, Instant Messaging, MSN, Skype, E-Mail and Whatsapp.

\section{Usage of Social Media for Educational Purposes}

Selwyn (2013) and Wild et al (2014) stated that social media is an important ICT tool that can be used to support learning activities. Social media technology is considered as a supporting mechanism that is useful to enhance face-to-face learning outside the classroom. Not only that, it's easy to use characteristics can help both lecturers and students to easily familiarize its technological functionalities, (Selwyn 2013:1 and Wild et al, 2014:715). Besides that, social media can be used as a collaborative learning platform where it allows collaboration on a bigger scale compared to the use of traditional media (e.g., e-mail or learning management systems). Not only that, using social media it enables lecturers and students to exchange and share information in real time.

Remarkably, Tess (2013) noted that social media has emerged as a highly useful personal communication technology that can give many advantages if being used in higher education. Lecturers can use social media as a platform to communicate with their students as long it a professional communication. Putting the responsibility to student's shoulders to learn using social media technology was made students succeeding beyond expectations (Tess, 2013:60). Basing on the above literature, it is observed that students can get a lot of benefits by using YouTube, one of the most popular social media sites, to learning some knowledge by watching videos from other expert or professional for free and without any time frame. 
Nevertheless, according to Ertmer, et. al (2012) integrating the use of social media in classroom activities can help lecturers to prepare their teaching activities more efficiently. An informal discussion before the class start can help students to prepare themselves. Not only that, based on student's feedback lecturers are able to have initial ideas on their students understanding on certain topics that they are going to teach. The use of social media in teaching activities can also give positive affect on collaborative learning and at the same time improve students' academic performance (Ertmer, et. al, 2012:423).

Similarly, social media provides new opportunities for innovating and modernizing Education and Training institutions and for preparing learners for the 21st century (Redecker et al., 2009). Additionally, social media technologies have the potential to support and enhance teaching and learning in higher education by providing learners with a chance to manipulate their learning environment and to participate actively in the learning process (Redecker et al., 2009:65). Up to recently, social media technologies have largely applied only in a social sphere; however a growing number of businesses are adopting enterprise social software technologies. It is through these collaborative technologies that students and knowledge workers will gain enhanced insight in the knowledge at their disposal. These tools will also enable information workers to locate and connect people with certain expertise across organizations, bringing people, systems and data into alignment faster to respond to challenges and take advantage of competitive opportunities.

In an educational context however, Selwyn (2007) state that "publicly open social media sites provide students with access to more information and experiences than they would get in a closed environment alone. If properly facilitated and framed, such expanded exposures can benefit student learning by creating more connections across boundaries and over time".

Yet, Valjataga and Fielder (2009:58) widely support the use of social media technology as a means of skilling students in preparation for the 'real world', "in order to be able to cope with many authentic challenges in increasingly networked and technologically mediated life we need to construct opportunities for participants in higher educational settings to practice the advancement of self-directing intentional learning projects." 


\section{Gratification of Social Media in Higher Education}

The uses and gratifications approach to communication studies examines what people do with the media. Uses and gratifications research has existed for more than five decades, at least since Herzog's (1940s) study of radio listening motives, Katz (1959), who wanted to combine the study of audience effects with studies of popular culture, gave the research its present name. Although media-effects studies have tended to overshadow uses and gratifications research, a substantial literature exists, (David, 2002:71).

Meanwhile, Quan-Haase and Young (2010) observed that one of the more successful theoretical frameworks from which to examine questions of "how" and "why" individuals use media to satisfy particular needs has been the uses and gratifications (U\&G) theory. Although $\mathrm{U} \& \mathrm{G}$ was originally developed to examine traditional media such as newspapers and television (Katz, Blumer, \& Gurevit, 1974; Katz, Gurevitch, \& Haas, 1973), recent studies have applied the framework to social media (Cited in Quan-Haase, and Young, 2010:2).

Contemporary Uses and Gratifications ( $U$ and $G$ ) theory tends to reflect assumptions; that people select and use communication source and messages to satisfy felt needs or desires. Media use is a mean to satisfy wants or interests such as seeking information to reduce uncertainty or to solve personal dilemmas. Social and psychological factors mediate communication behavior. (David, 2002:71) Uses and Gratification theory is a popular technique used in understanding user motivation for media use, access and understanding of their attitude towards a particular media. This study therefore, is based on the assumptions of uses and gratification theory to explore the usage and gratification of using social media in higher education in the scope international students.

Nevertheless, the motive for using a particular medium differs from person to the other depending on their sought gratification. Likewise, the reasons for social media usage in daily life of a student varies from communication, academic purposes, getting the latest news about friends, sports, politics, knowledge sharing, entertainment, socialization, playing games among others. Remarkably, students use a great variety of social media in higher education for different academic purposes, as observed by different scholars. Gülbahar (2014: 66) found that students use social media in their courses for communication with classmates, sharing of instructional resources, providing summaries, asking questions, taking exams, 
contributing to discussions, collaborative work, file sharing, evaluation and following announcements. But in most of the courses student use various social media environments for various purposes.

Marisol, G. et al (2011) observed that social media permit and favor the publication and sharing of information; self-learning; teamwork; communication, both between students and between pupil-teacher; feedback; access to other sources of information that support or even facilitate constructivist learning and collaborative learning; and contact with experts. As a whole, all of these applications and resources make learning more interactive and significant and above all allow it to develop in a more dynamic environment, (Marisol, Sergio \& Pedro, 201:21)

Observantly, the researcher in this current study agrees with Marisol, in that the use and familiarization of social media can be very helpful both in the learning phase and for the student's professional future, given that the vast majority of businesses are already employing such applications in the performance of their functions. Social media if appropriately used in higher education it can be used for enhancement of education as it provides a continuous method to follow the course and students can support each other and work in cooperation.

Nevertheless, face book as a social media platform, represents a potentially useful tool in educational contexts. It allows for both an asynchronous and synchronous, open dialogue via a familiar and regularly accessed medium, and supports the integration of multimodal content such as student-created photographs and video and URLs to other texts, in a platform that many students are already familiar with. Further, it allows students to ask more minor questions that they might not otherwise feel motivated to visit a professor in person during office hours to ask. It also allows students to manage their own privacy settings, and often work with the privacy settings they have already established as registered users. (Marisol, Sergio \& Pedro, 2011).

Basing on the above literature, it can however be observed that Facebook is one alternative means for shyer students to be able to voice their thoughts in and outside of the classroom as it allows students to collect their thoughts and articulate them in writing before committing to their expression. Further, the level of informality typical to Facebook can also aid students in 
self-expression and encourage more frequent student-and-instructor and student-and-student communication.

Social media are interactive and communication tools that are used by individuals, organizations and institutions for different purposes. It can be used for social interactions or for educational purposes. According to Christopher et al. (2015) social media plays an important role in scholarly communication. It is said to be a more interactive and usercentered communications technology. It enables participatory circulation of information and knowledge sharing in a simple and convenient way. Social media is a multidimensional instrument which enables knowledge sharing to satisfy students and researchers' needs in discussions and communications with others on interdisciplinary subjects. A variety of social media communication tools help to save students energy and offer wider channels to communication processes (Christopher, Vuyokazi, Mutibwa, and Scholarstica, 2015:3)

Similarly, Twitter also promotes social connections among students. It can be used to enhance communication building and critical thinking. For instance, Domizi (2013) utilized Twitter in a graduate seminar requiring students to post weekly tweets to extend classroom discussions. Students reportedly used Twitter to connect with content and other students. Additionally, students found it to be useful professionally and personally. According to Gao, Luo, and Zhang (2012) in their study concluded that Twitter allowed students to participate with each other in class (back channel), and extend discussion outside of class. They also reported that students used Twitter to get up-to-date news and connect with professionals in their fields. Students reported that micro blogging encouraged students to participate at a higher level.

YouTube is the most frequently used social media among students. For instance, with You tube students can watch videos, answer questions, and discuss content. Additionally, students can create videos to share with others. Sherer and Shea (2011) claimed that YouTube increased participation, personalization (customization), and productivity. YouTube also improved students' digital skills and provided opportunity for peer learning and problem solving with or without teachers. They further observed that videos kept students' attention, generated interest in the subject, and clarified course content. Additionally, the students 
reported that the videos helped them recall information and visualize real world applications of course concepts (Sherer \& Shea, 2011).

Whereas Quan-Haase \& Young (2010) in their factor analysis of gratifications obtained from Facebook revealed six key dimensions: pass time, affection, fashion, share problems, sociability, and social information. More so, their comparative analysis showed that Facebook is about having fun and knowing about the social activities occurring in ones' social network, whereas instant messaging was geared more toward relationship maintenance and development. (Quan-Haase \& Young 2010:1). Observantly, their findings on those two social media tools are more concerned with social interaction and non-academic activities than its usage in education.

The search tool in LinkedIn gives students the opportunity to seek out organizations they are interested in and allow them to learn more. Giving students the class time to work on their LinkedIn profile allows them to network with each other, and stresses the importance of networking. Finally, professors can design activities that revolve around resume building and interviews. A person's LinkedIn and resume are what employers look at first, and they need to know how to make a strong first impression. It's important to learn how to construct a strong resume as soon as possible, as well as learn strong interviewing skills (Sherer \& Shea, 2011).

\section{International Students' Higher Education in Turkey}

With the rapid internationalization of higher education in Turkey, Turkish universities are becoming an increasingly popular destination for students from around the globe. According to the 'International Student Research Project' report prepared by the Development Research Center, Turkey wants to attract 1.5 percent of all students from around the world who want to study overseas, as it continues to attract more international students, aiming to increase the current number of over 48,000 international students to 100,000 by the year 2018 . (Daily Sabah, 2015)

The growth of international students has been matched by the expansion of higher education in Turkey, where 50 public universities and 36 private foundation universities were established between 2006 and 2011, bringing the total number to 165. Accordingly, 80 
percent of international students in Turkey attend state universities, while 20 percent of them enrolled in foundation (private) universities in the 2013-2014 academic year. Additionally, 60 percent of all international students in Turkey attend universities in Istanbul, Ankara, İzmir, Konya and Erzurum. (http://www.dailysabah.com, 2016).

Notably, International students come from different continents in over 176 countries to study in Turkey. In 2011-2012, Azerbaijan had the biggest representation with more than 4,200 students, followed by Turkmenistan with 4,110 and the Turkish Republic of Northern Cyprus with about 3,800. Europe also showed strong numbers, with both Germany and Greece sending more than 1,300 students, data from Turkey's Council of Higher Education revealed. Africa's share has also increased in the last three years due to Turkey's policy toward the continent, which involves outreach and financial aid. (http://studyinturkey.com, 2016)

Conclusively, despite the fact that the researcher found the above literature relevant to the current study for instance, (Marisol, Sergio \& Pedro, 201: 21) revealed that social media permit and favor the publication and sharing of information; self-learning; teamwork; communication, both between students and between pupil-teacher; feedback; access to other sources of information that support or even facilitate constructivist learning and collaborative learning; and contact with experts.

However, the researcher in this study observed a gap in the varied reviewed literature in the way that no previous study focused on the information seeking behaviors of international students in higher education. Nevertheless, information seeking behavior is vital in media usage as it is related to the "information motivation" especially, how students use the social media for information and self-education. In nut shell this gap gives significance to why the current study is timely and paramount to be carried out.

\section{Methodology}

During this study, the researcher adopted case study research design, which is an empirical inquiry that investigates a contemporary phenomenon within its real-life context, especially when the boundaries between phenomenon and context are not clearly evident. More sore, the researcher employed quantitative technique. The essential method in this study was a descriptive survey in nature as the researcher sought to extrapolate the results to the surveyed 
population as a whole. Notably, a questionnaire was designed for data collection. A questionnaire has the ability to collect a large amount of information in a reasonably quick space of time (Ogunlade, Kamonges and Abdulkadir, 2015:199). The questionnaire was drafted and an exploratory pilot study was conducted. All the questions except for five were closed. The face and content validity of the instrument were ensured. The reliability coefficient of 0.7 was obtained which was judged to be high enough for the study

The questions explored the frequency with which the social media are used for different academic related activities in a normal week. In addition to these, the questionnaire obtained other socio-demographic data about the respondents. However, due to slow responses, data was collected from November 2015 to February 2016. The data obtained through the survey generated a database that was analyzed with the statistical packages. After reviewing and refining the data, the classic resources of descriptive statistics were used, such as summary statistics, frequency tables and charts.

The target population for this study comprised of all international students in Istanbul City, Turkey. The population size was set at over 5,000 students, according to the figures provided by the latest statistics available. (www.kalkinma.gov.tr, 2016). This study employed simple random sampling strategy to select the sample. In this regard, online questionnaires were delivered through several social media platforms namely, WhatsApp, individual and group email, Messenger and Facebook groups for international students in Istanbul. According to the response of the survey, 101 international students from 25 countries studying in 13 Universities in Istanbul City actively participated in the survey. Data collected was later analyzed using statistical and the results are reported in the consequent subsections.

\section{Limitation}

Although Istanbul city had more than 5000 international students pursuing higher education, only 101 responses were got due to time constraints which made the number of students involved in this study being small which made the sample not adequate for the study.

\section{Findings and Discussion}

In this subsection of this paper, the researcher presents details of the key finding from the field study as; 


\section{Demographic Characteristics of the Respondents}

After the survey, the final respondents were 101 students, from 27 nationalities studying in 13 Universities in Istanbul City, Turkey. The distribution of respondents as shown in the table 1, as by their gender $67.3 \%$ were male whereas 32.7 were female. Furthermore, the majority of the respondents were under the age group of 15-25 years who constituted $57.4 \%$, followed by those between 26-35, totaling to $41.6 \%$. Likewise, the academic levels of the respondents varied. But the majority was undergraduate students who composed of $48.5 \%$, followed by Master with 30.7\% and lastly Doctorate who made up 20.8\%. As far as the field of study for the respondents was concerned, as shown in table 1 below, $32 \%$ as the majority were under Social and Administrative Sciences, 31\% were offering Arts and Humanities, followed by $21 \%$ under Science, $11 \%$ Engineering and lastly 5\% were under Agriculture specialty.

Table 1, Showing the Demographic Characteristics of the Respondents

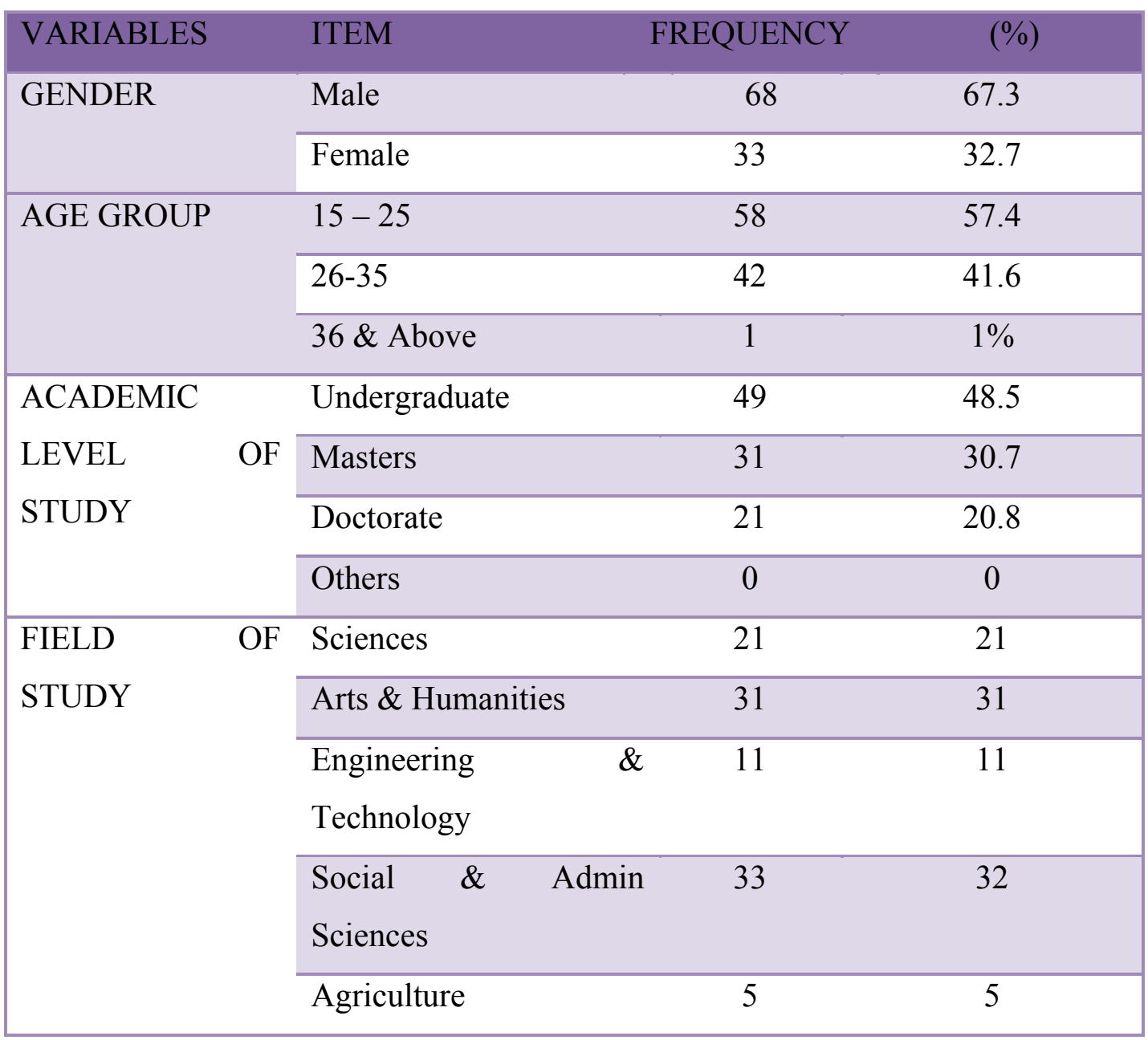

Source: Primary data, 2016 
Furthermore, during this study, responses were pursued about students' regularity in using social media to interact with classmates to study and work on class assignments outside of the classroom. As well as their frequency in using it while interacting with Professors to study and work on class assignments outside of the classroom. (Likert scale of 1 Never to 5 More than Twice a Week).

Findings as indicated in Table 2, shows that majority of the students represented by $68.2 \%$ of the respondents use social media for more than twice a week to interact with classmates to study and also work on class assignments outside of the classroom. In as far as their interaction with Professors to study and work on class assignments outside of the classroom, the study revealed that majority of the students represented by $44 \%$, used it more than twice a week. However, basing on these findings it is evident that students use social media among themselves and with their professors for academic purposes including course works and sharing of information.

Table 2, Showing Social Media (SM) Usage for interacting with Classmates \& Professors

\begin{tabular}{|l|l|c|c|c|c|c|}
\hline No. & TYPE & $\begin{array}{c}\text { Never } \\
\mathbf{( \% )}\end{array}$ & $\begin{array}{c}\text { Once or } \\
\text { Twice A } \\
\text { Semester } \\
\mathbf{( \% )}\end{array}$ & $\begin{array}{c}\text { Once or } \\
\text { Twice a } \\
\text { Month } \\
\mathbf{( \% )}\end{array}$ & $\begin{array}{c}\text { Once or } \\
\text { Twice a } \\
\text { Week } \\
\mathbf{( \% )}\end{array}$ & $\begin{array}{c}\text { More than } \\
\text { Twice a } \\
\text { Week (\%) }\end{array}$ \\
\hline 1 & $\begin{array}{l}\text { How often do you use } \\
\text { Social Media to interact } \\
\text { with Classmates }\end{array}$ & 3 & 2 & 3 & 23.8 & 68.2 \\
\hline 2 & $\begin{array}{l}\text { How often do you use } \\
\text { Social Media to interact } \\
\text { with Professors }\end{array}$ & 8 & 8 & 18 & 22 & 44 \\
\hline
\end{tabular}

Source: Primary data, 2016

Outstandingly, in line with essence of this study, as students perception on whether using different social media platforms such as Facebook, YouTube, Instant Messaging and others supports their educational learning, the study got varied perception as reflected in Pie Chart 1 , below. (Likert scale of 1 Strongly Disagree to 5 Strongly Agee). Findings showed that 
majority of the international students composing of $37 \%$ agreed that using different social media platforms such as Facebook, YouTube and others supports their educational learning, whereas $36 \%$ strongly agreed with the same assertion. However, $17 \%$ of the respondents had a neutral perception and only $10 \%$ disagreed.

\section{Chart 1, Showing Students' Perception on Usage of SM in Support of their Learning}

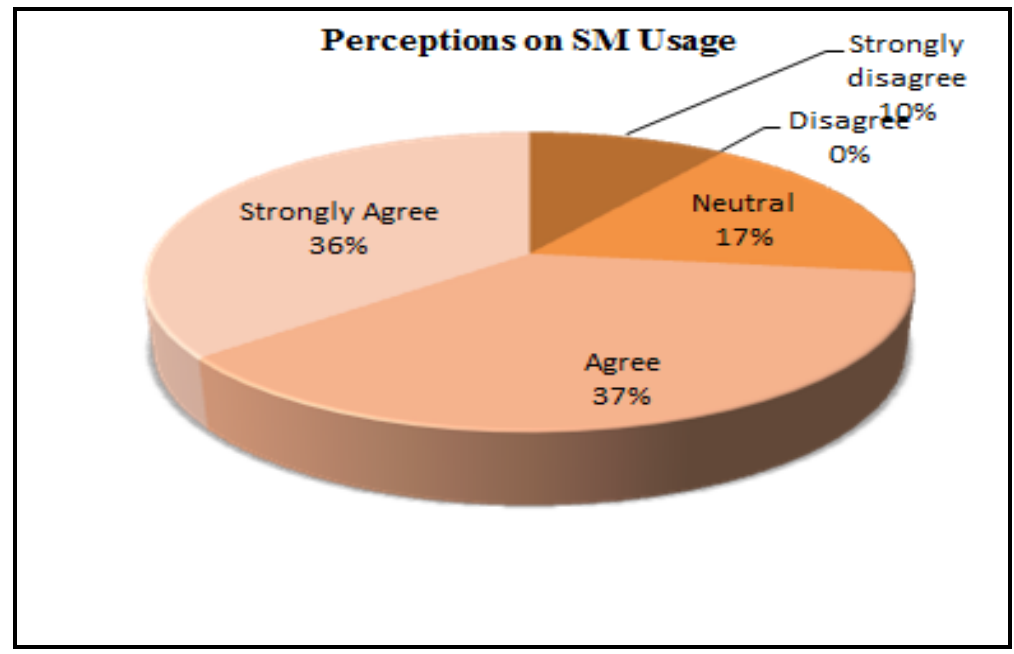

Source: Primary data, 2016

\section{Social Media Tools Used by International Students}

As Bueltner (2015) identified a number of social media tool which are used by students for educational purposes, like You Tube, Face book among others, findings of this study indicate that students frequently used different tools, although others denominated as reflected in table 3, below. (Likert scale of 1 Never 5 Very Often). The study revealed that $55.4 \%$ of the respondents very often used YouTube to watch educational video-clips compared to other plat form. As also seen in their gratification they used You Tube to watch lectures from other universities, to learn Turkish and to repeat lessons. In the second position, $36.6 \%$ of the respondent affirmed their usage of Whatsapp for instant messaging and academic update.

The study further discovered that $34.7 \%$ of the respondents asserted that they very often used online networks like MSN, Google group and Facebook for sharing educative information with their classmates and Professors. This is also consistent with the findings on their gratification as discussed in subsection 4.3 below. However, other tools are less used by 
students as reflected in the findings. For example, $28.8 \%$ as the biggest percentage never used Twitter and LinkedIn for sharing academic information with academicians and only 19.8 of the respondents often used those platforms. Other least used tools also included Skype for video/voice group calls to discuss academic assignments, $35 \%$ as the majority respondents never used it. Likewise, Wikipedia to get general ideas had minimal usage where by only $28.7 \%$ only often used it.

Table 3, Showing the Social Media Tools Used by International Students

\begin{tabular}{|c|c|c|c|c|c|c|}
\hline No. & TYPE & $\begin{array}{c}\text { Never } \\
(\%)\end{array}$ & $\begin{array}{c}\text { Some } \\
\text { times } \\
(\%)\end{array}$ & $\begin{array}{l}\text { Not } \\
\text { Sure } \\
(\%)\end{array}$ & $\begin{array}{l}\text { Often } \\
\text { (\%) }\end{array}$ & $\begin{array}{c}\text { Very } \\
\text { Often } \\
(\%)\end{array}$ \\
\hline 1 & $\begin{array}{l}\text { How often do you use S.M for } \\
\text { learning }\end{array}$ & 1 & 11.9 & 5.9 & 26.7 & 54.5 \\
\hline 2 & $\begin{array}{l}\text { How often do you use YouTube to } \\
\text { watch educational video-clips }\end{array}$ & 2 & 5.9 & 10.9 & 25.7 & 55.4 \\
\hline 3 & $\begin{array}{l}\text { Use of Online networks like MSN, } \\
\text { Google group \& Facebook for sharing } \\
\text { educative information with my } \\
\text { classmates and Professors. }\end{array}$ & 4 & 16.8 & 11.9 & 32.7 & 34.7 \\
\hline 4 & $\begin{array}{l}\text { Use of Twitter and LinkedIn for } \\
\text { sharing academic information with } \\
\text { academicians }\end{array}$ & 28.7 & 18.8 & 15.8 & 19.8 & 16.8 \\
\hline 5 & $\begin{array}{l}\text { Use E-mail services for learner- } \\
\text { instructor as well as learner-learner } \\
\text { interactions }\end{array}$ & 16.8 & 22.8 & 11.9 & 17.8 & 30.7 \\
\hline 6 & $\begin{array}{l}\text { Do you use Wikipedia to get general } \\
\text { ideas }\end{array}$ & 6.9 & 26.7 & 9.9 & 27.7 & 28.7 \\
\hline 7 & $\begin{array}{l}\text { How often do you use Skype for } \\
\text { video/voice group calls to discuss } \\
\text { academic assignments }\end{array}$ & 35 & 19 & 14 & 18 & 14 \\
\hline 8 & $\begin{array}{l}\text { How often do you use Whatsapp for } \\
\text { Instant messaging \& academic }\end{array}$ & 14.9 & 17.8 & 8.9 & 36.6 & 21.8 \\
\hline
\end{tabular}


updates

Source: Primary data, 2016

\section{The Educational Purposes for Using Social Media}

As the principal objective of this research of exploring the academic use of social media that students make, the researcher probed it with an open ended question on this aspect to get varied views from the respondents. The majority of respondents indicated that they use social media for watching educative videos on You Tube channel for lectures done at other universities to widen on their understanding of a particular topic. Similarly, watching educational videos on You Tube so that they could improve on their Turkish language especially the listening and speaking skills plus learning some new words used in those videos especially Turkish movies. Some observed that sometımes it is a little bit difficult to understand professors during the lecture. So they alternatively use YouTube and other social media platforms to learn things that they didn't understand during the lecture as they find social media both educative and entertaining by watching interesting videos. More so, another educational purpose was personal discovery and getting in-depth knowledge on issues taught in class when they are at their residences and in the absence of their professors. Sometimes sharing information with fellow classmates on homework and other tasks given to them by their professors also motivated them to use social media especially, face book and Whatsapp as they could help one another in doing academic work. Accessing online information online videos, papers from different journals and online books where they had no or less access to the library hence fostering research output and discussion. It bridges the gap and enables them to easily get instant responses from peers and course mates. Likewise it facilitated contacting with their professors without any fear.

However, beside students' usage of social media for education purposes, they also had other motivations. Namely; sharing ideas with friends and communicating to family and friends about social and current issues. This was important to them too as it helped them to decrease stress after exhausting academic works hence strengthened them academically. Getting some important information about scholarships, social, environment and to get up-to-date information about economy and politics around the globe. 


\section{Academic Gratification got in Using Social Media}

As the contemporary uses and gratifications theory posits that media consumption is purposive and users actively seek to fulfill their needs through a variety of uses (David, 2002:71). This was also observed in the findings of this study as students had different gratifications gained from using social media. As reflected in table 4, below. (Likert scale of 1 Strongly Disagree to 5 Strongly Agee). Findings concluded that $42.6 \%$ agreed and $28.6 \%$ strongly agreed with the assertion that social media enables them to interact with their professors and with their classmate. This implies that these respondents used social media to full fill their need for interaction with those two categories.

Similarly, $45.5 \%$ of the respondents agreed and 29.7 strongly agreed that they use social media to full fill their information need thus enabling them to get ideas on related subjects from group forums like Facebook, Whatsapp and other groups. Remarkably, 43.6\% of the respondents agreed that their gratification attained from using social media was sharing of their research findings with their classmates. This gratification is in line with the educational use of social media likewise $41.6 \%$ observed that they gain from social media as it enables them contact peers and discuss relevant issues and enhance collaborative learning. Meanwhile, 39.6\% agreed that they benefited from social media as they use it for classroom announcements to fellow students and discussion of academic issues, hence making the platform useful in their education endeavors.

Table 4, Showing the Students' Gratification attained in Using Social Media

\begin{tabular}{|c|c|c|c|c|c|c|}
\hline No & Opinion & $\begin{array}{l}\text { S. } \\
\text { Disagree } \\
\text { (\%) }\end{array}$ & $\begin{array}{l}\text { Dis } \\
\text { agree } \\
(\%)\end{array}$ & $\begin{array}{l}\text { Neutral } \\
(\%)\end{array}$ & $\begin{array}{l}\text { Agree } \\
(\%)\end{array}$ & $\begin{array}{l}\text { S. } \\
\text { Agree } \\
(\%)\end{array}$ \\
\hline 1 & $\begin{array}{l}\text { S.M enables me interact with } \\
\text { my professors \& peers }\end{array}$ & 4 & 10.9 & 13.9 & 42.6 & 28.6 \\
\hline 2 & $\begin{array}{l}\text { S.M enables me to get ideas on } \\
\text { the related subjects from group } \\
\text { forums. }\end{array}$ & 6.9 & 7.9 & 9.9 & 45.5 & 29.7 \\
\hline 3 & $\begin{array}{l}\text { I use S.M as a platform for } \\
\text { sharing my research findings }\end{array}$ & 7.9 & 5 & 9.9 & 43.6 & 33.7 \\
\hline
\end{tabular}




\begin{tabular}{|lllllll|}
\hline \multicolumn{2}{|l|}{ with my classmates } \\
\hline 4 & $\begin{array}{l}\text { S.M enables me contact peers } 3 \\
\text { and discuss relevant issues and } \\
\text { enhance collaborative learning }\end{array}$ & 5.9 & 9.9 & 41.6 & 39.6 \\
\hline 5 & I use S.M for classroom 10.9 & 4 & 8.9 & 39.6 & 36.6 \\
& $\begin{array}{l}\text { announcements to fellow } \\
\text { students and discussion of } \\
\text { academic issues }\end{array}$
\end{tabular}

Source: Primary data, 2016

\section{Conclusion and Recommendation}

Basing on the data obtained, the respondents who participated were from different nationalities and backgrounds which could also impact on their usage of social media in academics. By and large the majorities were male, undergraduate and in the age group of 1525 who were under Social and Administrative Sciences specialties. Findings shows that majority of the students represented by $68 \%$ of the respondents use social media more than twice a week to interact with classmates to study and also work on class assignments outside classroom environment.

In as far as their interaction with Professors to study and work on class assignments outside the classroom, the study revealed that majority of the students represented by $44 \%$, used it more than twice a week. Findings showed that majority of the international students composing of $37 \%$ agreed that using different social media platforms such as Facebook, YouTube, Whatsapp and Tweeter supports their educational learning, whereas 36\% strongly agreed with the same assertion. As $55.4 \%$ of the respondents very often used YouTube to watch educational video-clips compared to other plat form. Also seen in their gratification they used You Tube to watch lectures for other universities, to learn Turkish and to repeat lessons. In the second position, $36.6 \%$ of the respondent affirmed their usage of Whatsapp for instant messaging and academic update.

In line with Quan-Haase \& Young (2010) who found six key dimensions of gratifications obtained from Facebook namely; pastime, affection, fashion, share problems, sociability, and social information. This study also revealed that some respondents expressed some negative 
aspects of social media in their academic learning, despite the numerous advantages to their education. Some of the perceived negative aspects included; time wastage, as some students waste much of their time by chatting or using different type of alternative which has nothing to do with the academic learning. Sometimes some of information spread out by social media is not authentic and credible in academia hence cannot be referenced. Likewise learning by social media do not permit extensive discussion, thinking and the learner loses feeling of learning, which they can get in face to face interaction with the teacher. Some students use media for fun like posting nude pictures, videos and others use it to express their anger and ego.

Consequently upon the findings, it can be concluded that social media although in the past it was merely a social network of creating and chatting with friends, Social Media have a number of affordances that can make them useful in teaching and learning environments as it can support pedagogical approaches of active learning; social learning and student publication, by providing environments and technologies that promote these interactions. We can use social media technology as a powerful networking for knowledge sharing among international students in Turkey.

Recommendations: Based on the findings, the study recommends the adaptation and the adoption of social media in the educational system prior to modern technology prosperity. I strongly encourage this because the academic learning system which involves the use of social media has already of course existed but in a very low percentage of the world's academic learning tradition, therefore I encourage the rapid contemplation of its importance by many universities. In academic learning it is good because for some student especially in practical disciplines like in laboratories if there is experimental apparatus students can easily learn from You Tube and other social Media and can further be used as a demonstrative platform. However, a general course can be provided to new international students in Turkey especially undergraduates about social media usage in education like computer literacy courses so that they can make good use of it in line with their higher education.

As a conclusion, social media is slowly being accepted as one of the facilitating tools to help lecturers conduct their class more effective and interactive. However, to be able to manipulate the full potential of this platform, awareness on how to operationalize the 
platform and control the risk of using this platform needs to be provided. Hands on training need to be conducted to educate the majority adopters of lecturers who are interested to use the platform for teaching purposes. Finally, a study can be conducted on the "Information seeking behaviors of international Students: A comparative study on Radio, TV and Internet. 


\section{Reference}

Buettner, R. (2015). Getting a Job via Career-oriented Social Networking Sites: The Weakness of Ties. 49th Annual Hawaii International Conference on System Sciences. Kauai, Hawaii, https://www.linkedin.com/pulse/social-media (Accessed 13/3/2016)

Christopher, Owusu-Ansah, Vuyokazi Gontshi, Lois Mutibwa, and Scholarstica Ukwoma (2015) “Applications of Social Media and Web 2.0 for Research Support in Selected African Academic Institutions" Journal of Balkan Libraries Union Vol. 3, No. 1, pp. 30-39, 2015.

David, K. Perry (2002) Theory and Research in Mass Communication Contexts and Consequences $2^{\text {nd }}$ Ed, New Jersey: Lawrence Erlbaum Associates Publishers.

Domizi, Denis (2013). Micro blogging to foster connections and community in a weekly graduate seminar course. TechTrends, 57(1), 43-51.

Ertmer, P. A. Ottenbreit-Leftwich, A. T. Sadik, O. Sendurur, E. and Sendurur, P. (2012). Teacher Beliefs And Technology Integration Practices: A Critical Relationship. Computers \& Education. 59(2):423-435.

Gao, Fie ; Luo Tian \& Zhang Ke (2012). Tweeting for learning: A critical analysis of research on micro blogging in education" http://onlinelibrary.wiley.com (Accessed: 26/02/2016)

Gülbahar, Yasemin (2014). "Current State of Usage of Social Media for Education: Case of Turkey", Journal of Social Media Studies, 1(1) pp. 53-69

Gómez, Marisol; Roses Sergio and Farias Pedro (2012). A Descriptive Study of the Academic Use of Social Networks among University Students. Scientific Journal of Media Education. http://www.revistacomunicar.com (Accessed: 16/03/2016)

Naghmeh M. Aghaee (2010) "Social Media Use in Academia: Campus Students Perceptions of How Using Social Media Supports Educational Learning”, Magister thesis, Uppsala University, Department of Computer and System Science, Uppsala, Sweden.

Ogunlade, J.Olurotimi; Kamonges Wahab, and Abdulkadir Abdulrauf (2015).

"Motivational Factors and Teachers Commitment in Public Secondary Schools in Mbale Municipality", Journal of Education and Practice, 6(15) pp. 2222-1735

Quan-Haase, Anabel \& Young Alyson (2010).“Uses and gratifications of social media: A comparison of Facebook and instant messaging "Bulletin of Science, Technology and Society, 30(5), 350-361.

Redecker, C., K. Ala-Mutka, M. Bacigalupo, A. Ferrari and Y. Punie (2009). Learning 2.0: 
The Impact of Web 2.0 Innovations on Education and Training in Europe. Final Report. JRC Scientific and Technical Report, EUR 24103 EN:

http://ipts.jrc.ec.europa.eu/publications/pub.cfm?id=2899.

Redecker, C., Ala-Mutka, K. and Punie, Y. (2010) Learning 2.0 - The Impact of Social Media on Learning in Europe, JRC Scientific and Technical Report, http://www.ict21.ch/com-ict/IMG/pdf/learning-2.0-EU-17pages-JRC56958.pdf

Selwyn, N. (2007) "Web 2.0 applications as alternative environments for informal learning a critical review" http://www.oecd.org/dataoecd/31/37/39459090.pdf, Accessed $16 / 2 / 2016$

Selwyn, N. (2013). Social Media In Higher Education. Europa World Learning.1:1-10.

Sherer, Pamela \& Shea, Timothy. (2011). "Using online video to support student learning and Engaging College Teaching” https://www.learntechlib.org (Accessed 13.12.2015)

Tess, P. A. (2013). The Role Of Social Media In Higher Education Classes (Real And Virtual)- A Literature Review. Computers in Human Behavior. 29(5):60-68.

Valjataga, T. and Fielder, S. (2009) "Supporting students to self-direct intentional learning projects with social media", Educational Society, 12 (3), 58-69.

Wild, J. A. Cant, M. C. and Nell, C. E. (2014). Perceptions And Uses Of Social Media Networking Systems By South African Students. International Business \& Economics Research Journal (IBER). 13(4):715-726.

http://www.kalkinma.gov.tr/Lists/Yaynlar/Attachments/647/Uluslararasi_Ogrenci_Raporu_2 015.pdf.pdf (Accessed 12/1/2016)

http://www.dailysabah.com/education/2015/05/07/turkey-aims-to-educate-100000international-students-in-2018 (Accessed 18.03.2016)

http://studyinturkey.com/content/sub/turkey_grows_as_destination_for_international_studen (Accessed 18.01.2016)

http://www.ebizmba.com/articles/social-networking-websites (Accessed 19.3.2016) 